\title{
Stable isotope evidence of long-term changes in the North Sea food web structure
}

\author{
Jens Tang Christensen ${ }^{1}$, Katherine Richardson ${ }^{1,2, *}$ \\ ${ }^{1}$ Department of Biological Sciences, Marine Ecology, University of Aarhus, Finlandsgade 14, 8200 Aarhus N, Denmark \\ ${ }^{2}$ Faculty of Natural Sciences, Copenhagen University, Øster Voldgade 3, 1350 Copenhagen $K$, Denmark
}

\begin{abstract}
A temporal change in stable isotope $\left(\delta^{15} \mathrm{~N}\right)$ distributions in North Sea harbour porpoises Phocoena phocoena (L.) was documented by analysing stable isotope abundances in bone collagen from 88 skeletons of harbour porpoises stranded in the period between 1848 and 2002 along the southern North Sea coast. Porpoises collected after $\sim 1960$ had significantly lower $\delta^{15} \mathrm{~N}$ than porpoises collected earlier. This change in $\delta^{15} \mathrm{~N}$ implies that fundamental changes in food web structure in, or nutrient availability to, the North Sea have taken place over the last $\sim 150 \mathrm{yr}$ and that most of the change occurred over a relatively short period in the middle of the 20th century. Harbour porpoises are generalist feeders and their diet largely reflects the food available to them. Thus, one plausible explanation for the observed change in $\delta^{15} \mathrm{~N}$ could be that harbour porpoises in the North Sea have, since the mid-20th century, been feeding at a lower trophic level than during the preceding century, i.e. animals from lower trophic levels may now be more dominant than they were prior to the middle of the 20th century. There is no a priori reason to suspect that a change in isotope distributions at the base of the food web has occurred during this period and we have not been able to find material that would allow us to test the assumption that there has been no temporal development of $\delta^{15} \mathrm{~N}$ at the lowest levels of the food web. Thus, we cannot eliminate the possibility that the change in $\delta^{15} \mathrm{~N}$ in harbour porpoise skeletons reported here may be a reflection of a change in the isotope signature of nitrogen entering the food web. Regardless of its underlying cause, the recorded change in isotopic signature in harbour porpoises is noteworthy as it represents the first fisheries-independent documentation of a long-term temporal change in the structure or function of the pelagic ecosystem in the North Sea.
\end{abstract}

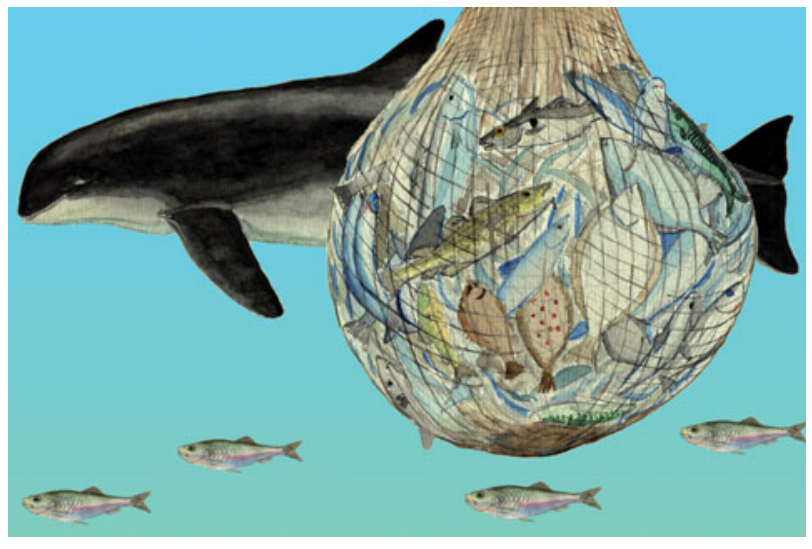

Skeletons of top predators provide a record of long-term changes in ecosystem structure.

Graphic: J. T. Christensen

KEY WORDS: Stable isotopes - Food web structure · North Sea $\cdot$ Harbour porpoise Resale or republication not permitted without written consent of the publisher

\section{INTRODUCTION}

Documenting long-term changes in offshore aquatic ecosystems is notoriously difficult as, with the exception of commercial fisheries monitoring and catch data, there are very few time series of abundances of organisms in, or other data pertaining to, open marine ecosystems. On the basis of an analysis of the Food and Agriculture Organization's (FAO) fisheries statistics, Pauly et al. (1998) argued that major changes in the 
trophic structure of marine ecosystems may have occurred due to the removal of top predators by intensive fisheries. Their study indicated that the smaller fish, i.e. fish of lower trophic levels, have become more dominant in fish catches in a number of different marine areas in recent decades. That paper attracted considerable attention and has led to an ongoing debate concerning the possible 'fishing down' of marine ecosystems. Some researchers whose studies are also based on fish-catch data sets (e.g. Pinnegar et al. 2002) support Pauly et al.'s (1998) conclusions concerning the fishing down of ecosystems while others (e.g. Essington et al. 2006) argue that observed changes in pelagic ecosystems do not necessarily reflect the removal of top predators.

The fact that fisheries-catch data from many regions, including the North Sea, imply that there may have been a temporal change in pelagic ecosystem structure is intriguing. However, there are 2 inherent weaknesses in using commercial fisheries-catch data to describe changes in ecosystems. Firstly, such data are influenced by the market economy and human behaviour. As a result, changes in fish catch may not reflect real changes in ecosystem structure. For example, it can be argued that the greater relative proportion of small fish in landings in recent decades may be a reflection of the development of industrial fisheries providing a greater market for smaller fish. The other problem is that records of commercial fish catch have only been maintained for a relatively short time period. Thus, it is difficult to determine whether changes observed represent a fundamental change in ecosystem structure or natural fluctuations in ecosystem structure. To some extent, the problems associated with commercial catch data being influenced by the economic market can be overcome by using monitoring data collected in connection with fisheries assessment. However, such data series are even shorter than data series for commercial catches. Thus, it is difficult to put any changes seen in the size structure of catches made in assessment studies into a long-term perspective. Therefore, in order to confirm temporal changes in the trophic structure of pelagic ecosystems suggested by studies based on fisheries statistics, there is a need for an approach which is independent of fisheries data. Distributions of stable isotopes in biological material may provide such an approach.

There is, in general, an enrichment of around $3 \%$ in $\delta^{15} \mathrm{~N}$ of an animal's tissues compared to its diet (e.g. Michener \& Schell 1994, Post 2002). Tissue $\delta^{13} \mathrm{C}$ is usually determined concomitantly with $\delta^{15} \mathrm{~N}$ and $\delta^{13} \mathrm{C}$ is generally assumed to be the same (within about $1 \%$ ) as the animal's dietary carbon source, although trophic enrichment in ${ }^{13} \mathrm{C}$ is reported from marine ecosystems (Kelly 2000). Hence, $\delta^{15} \mathrm{~N}$ indicates the trophic level at which the animal feeds while $\delta^{13} \mathrm{C}$ is believed to trace dietary carbon sources. This means that natural stable isotope signatures can be used as indicators of food web relationships in ecosystems.

In freshwater systems, stable isotope ratios have in recent years been relatively often used to describe food web structure (Cabana \& Rasmussen 1996, Vander Zanden et al. 1999b, Post 2002) and changes in food web structure after, for example, the introduction of a new predator into the ecosystem (Vander Zanden et al. 1999a). Both because they are less accessible and because they are usually more open than freshwater systems, knowledge of marine ecosystems is, as a rule, not as detailed as for those in freshwater. However, inspired by such studies in freshwater systems, we reasoned that the top predators in the North Sea food web are 'fishers' that are not influenced by market forces and the trophic level of their diet can be derived from their nitrogen stable isotope abundances $\left(\delta^{15} \mathrm{~N}\right)$. Bone collagen has a relatively long turnover time and its isotopic composition should therefore reflect feeding habits over a long period of the animal's life (Kelly 2000, Dalerum \& Angerbjörn 2005). Thus, the bone collagen of top predators should contain an isotope signal that reflects long-term trends in the animals' diet.

The harbour porpoise Phocoena phocoena (L.) is a top predator in the North Sea ecosystem. It is a generalist feeder, meaning that it does not exhibit preferences for specific species or types of food. Thus, its diet can be expected to reflect the relevant food items to which the animal is exposed. The harbour porpoise's diet consists primarily of fish but also includes crustaceans and cephalopods (Santos \& Pierce 2003). Changes in fish community composition can therefore be expected to be reflected in changes in the species and/or size composition in the diet of these porpoises. The purpose of the present study was to establish a time series for stable nitrogen isotope distributions in harbour porpoises from the southern North Sea and to infer from this time series possible historical changes in the structure of the food web in this marine system.

\section{MATERIALS AND METHODS}

We determined the $\delta^{15} \mathrm{~N}$ and $\delta^{13} \mathrm{C}$ of bone collagen from a collection (National Museum of Natural History, Leiden, Netherlands) of 88 skeletons of harbour porpoises stranded on the Dutch North Sea coast during the period 1848 to 2002. Most of the individuals, however, were from the period 1940 to the present. The porpoises are all assumed to derive from North Sea populations. Bone samples were taken from the base of skulls between the occipital condyles and from the body from vertebrae. 
A number of different protocols have been employed to extract organic fractions from fossil bones for stable isotope analysis and ${ }^{14} \mathrm{C}$ dating (e.g. Minami et al. 2004, Ramsey et al. 2004) with the aim of removing humic substances and other contaminants while preserving the isotopic composition of bone collagen. As humic substances were not considered to be a problem in our museum specimens, we employed a simplified protocol. Samples were extracted with an electric drill. From each sample, approximately $1.5 \mathrm{~g}$ of ground bone material was put into a $10 \mathrm{ml}$ centrifuge tube and sequentially extracted with hexane, acetone, ethanol and water to remove lipids and water-soluble contaminants. For each of these steps, tubes with samples and $10 \mathrm{ml}$ solvent were sonicated (60 $\mathrm{min})$ and then left for $24 \mathrm{~h}$. Samples were then demineralised in $2 \% \mathrm{HCl}$ until no gas bubbles were produced, and then washed with distilled water. Finally, base-soluble contaminants were removed with $0.1 \mathrm{~N} \mathrm{NaOH}$ and samples washed with distilled water. The resultant collagen was transferred to $2 \mathrm{ml}$ Eppendorf tubes and freezedried. Dried collagen, 1 to $2 \mathrm{mg}$, from each sample was weighed into tin capsules for continuous-flow isotope ratio mass spectrometry (CF-IRMS) analysis using a Europa Scientific ANCA-NT 20-20 Stable Isotope Analyser with ANCA-NT Solid/Liquid Preparation Module at the Scottish Crop Research Institute, Dundee. The CF-IRMS was operated in the dual-isotope mode, allowing $\delta^{15} \mathrm{~N}$ and $\delta^{13} \mathrm{C}$ to be measured on the same sample. The analytical precision ( $\mathrm{SD}, \mathrm{n}=5$ ) was $0.2 \%$ for both $\mathrm{N}$ and $\mathrm{C}$, estimated from standards analysed along with the samples. Working standards were $1 \mathrm{mg}$ leucine prepared by freeze-drying $50 \mu \mathrm{l}$ of a $20 \mathrm{mg}$ $\mathrm{ml}^{-1}$ stock solution into tin cups and calibrated against 'Europa flour' and International Atomic Energy Agency (IAEA) standards N1 and N2. The methods are fully described in Scrimgeour \& Robinson (2003).

Data are reported as $\delta^{13} \mathrm{C}$ and $\delta^{15} \mathrm{~N}$ values relative to known standards, Pee Dee belemnite for ${ }^{13} \mathrm{C}$ and atmospheric $\mathrm{N}$ for ${ }^{15} \mathrm{~N}$ according to the formula:

$$
\delta \mathrm{I}=\left[\left(\mathrm{R}_{\text {sample }} / \mathrm{R}_{\text {standard }}\right)-1\right] \times 1000
$$

where $\mathrm{I}$ is ${ }^{13} \mathrm{C}$ or ${ }^{15} \mathrm{~N}$ and $\mathrm{R}$ is the ratio of the heavy to the light isotope $\left({ }^{13} \mathrm{C} /{ }^{12} \mathrm{C}\right.$ or $\left.{ }^{15} \mathrm{~N} /{ }^{14} \mathrm{~N}\right)$.

To detect discontinuities in the unevenly distributed time series of individual isotope ratio values, data were arranged chronologically and a split moving-window analysis was performed. The analysis is a modification of the method used by Webster (1973) to detect boundaries in soil analysis and by Ludwig \& Cornelius (1987) to detect discontinuities along ecological gradients. At the beginning of the time series, a window consisting of the first 16 records was introduced. This window was split in 2 and the probability associated with the difference between the medians of the 2 half-windows was then calculated (Mann-Whitney $U$-test). The window was subsequently moved 1 record up the time series and the procedure repeated until the end of the time series was reached. Linear relationships between $\delta^{15} \mathrm{~N}$ and $\delta^{13} \mathrm{C}$ were analysed by standardised major axis (SMA) (Warton et al. 2006) using routines and tests in the program (S)MATR (SMATR: standardised major axis tests and routines, version 2.0, accessed 4 December 2006 from: www.bio.mq.edu.au/ecology/ SMATR/).

\section{RESULTS}

The C:N ratios of the extracted collagen samples ranged from 2.8 to 3.2 and did not show a temporal trend. There was no difference in $\mathrm{C}: \mathrm{N}$ ratios between the sexes. Among the 88 porpoises analysed for stable isotope signatures, 3 pups and a carcass that had been buried for $5 \mathrm{yr}$ had high values of $\delta^{15} \mathrm{~N}$ (Fig. 1). As nursing pups literally feed on their mothers and microbial degradation may affect isotopic signatures of bone collagen (e.g. Balzer et al. 1997), these 4 animals were omitted from further analysis. Among the remaining 84 porpoises, a significant decrease in $\delta^{15} \mathrm{~N}$ was recorded over the study period (Mann-Kendall test, MK-stat. $=-4.086, \mathrm{p}<0.0001)$. The $\delta^{15} \mathrm{~N}$ remains relatively stable until about 1960, when it begins to decline, with the lowest overall values being recorded for the mid- to late 1970s. As is usual with natural abundances, there is considerable variation in the data. The sex of 24 individuals was unknown but for the remaining animals, sexes were evenly dispersed in time. In

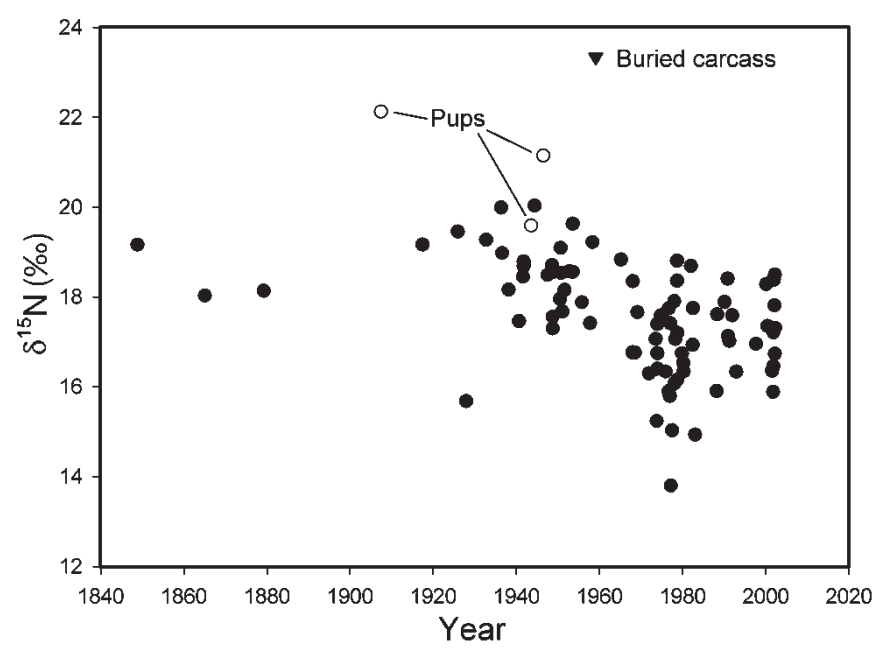

Fig. 1. Phocoena phocoena. Bone collagen $\delta^{15} \mathrm{~N}$ values of individuals stranded on the Dutch North Sea coast. Data are from 88 animals stranded between 1848 and 2002. Values for 3 pups and a carcass that was buried for $5 \mathrm{yr}$ are shown but were omitted from the data analysis 


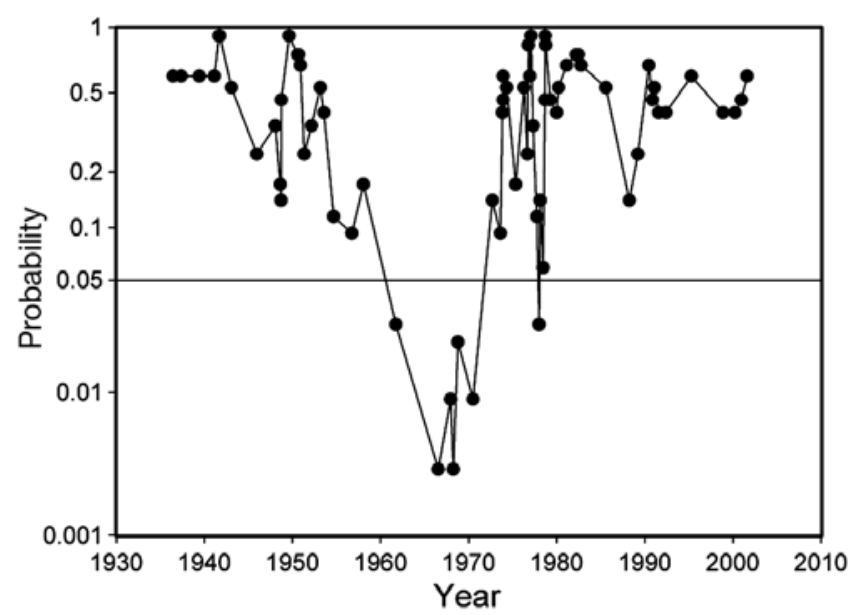

Fig. 2. Phocoena phocoena. Discontinuity analysis of $\delta^{15} \mathrm{~N}$ values of bone collagen. Probability associated with pairwise Mann-Whitney $U$-test comparisons in a split moving-window analysis (width of window 16 data points). Probabilities are plotted against the median date of the corresponding window

the data set as a whole, there was no significant difference between males $\left(\delta^{15} \mathrm{~N}\right.$, mean $\left.\pm \mathrm{SD}=17.56 \pm 1.25\right)$ and females $\left(\delta^{15} \mathrm{~N}\right.$, mean $\left.\pm \mathrm{SD}=17.25 \pm 1.12\right)$ but a difference was noted in one of the subsets of data considered (see final paragraph in this section). Signatures of $\delta^{13} \mathrm{C}$ and $\delta^{15} \mathrm{~N}$ were correlated (Spearman's $\rho=$ $0.687, \mathrm{p}<0.01$; data not shown) and a negative trend in $\delta^{13} \mathrm{C}$ with time was found (MK-stat. $=-1.982, \mathrm{p}=$ 0.047 ). This trend was however not significant in the 2-tailed Mann-Kendall test.

The discontinuity analysis (Fig. 2) shows major changes occurring in $\delta^{15} \mathrm{~N}$ through the 1960s and in

Table 1. Result of standardised major axis (SMA) analysis of bivariate data $\left(\delta^{15} \mathrm{~N}\right.$ and $\delta^{13} \mathrm{C}$ ) from groups of harbour porpoises identified by a discontinuity analysis

\begin{tabular}{|lcccccc|}
\hline Group & Years & $\begin{array}{c}\text { SMA } \\
\text { slope }\end{array}$ & $\begin{array}{c}\text { Lower } \\
\text { CI }\end{array}$ & $\begin{array}{c}\text { Upper } \\
\text { CI }\end{array}$ & Intercept & $\mathrm{R}^{2}$ \\
\hline 1 & $1848-1958$ & 0.703 & 0.516 & 0.957 & -24.819 & 0.317 \\
2 & $1971-1978$ & 1.036 & 0.727 & 1.476 & -29.642 & 0.637 \\
3 & $1978-2002$ & 0.861 & 0.687 & 1.078 & -27.053 & 0.616 \\
\hline
\end{tabular}

Table 2. Line intercepts and probabilities associated with Tukey-Kramer post hoc comparisons between groups in the SMA analysis for a common slope of $0.851 . \mathrm{ns}=$ not significant

\begin{tabular}{|c|c|c|c|c|c|c|c|c|}
\hline \multirow[t]{2}{*}{ Group } & \multirow[t]{2}{*}{ Years } & \multirow[t]{2}{*}{$\begin{array}{l}\text { Inter- } \\
\text { cept }\end{array}$} & \multicolumn{3}{|c|}{$\begin{array}{l}\text { Shift in } \\
\text { elevation }\end{array}$} & \multicolumn{3}{|c|}{$-\begin{array}{c}\text { Shift along } \\
\text { common slope }\end{array}$} \\
\hline & & & 1 & 2 & 3 & 1 & 2 & 3 \\
\hline 1 & 1848-1958 & -27.565 & - & 0.0001 & 0.0001 & - & 0.0001 & 0.0006 \\
\hline 2 & 1971-1978 & -26.628 & & - & ns & & - & 0.0197 \\
\hline 3 & 1978-2002 & -26.889 & & & - & & & - \\
\hline
\end{tabular}

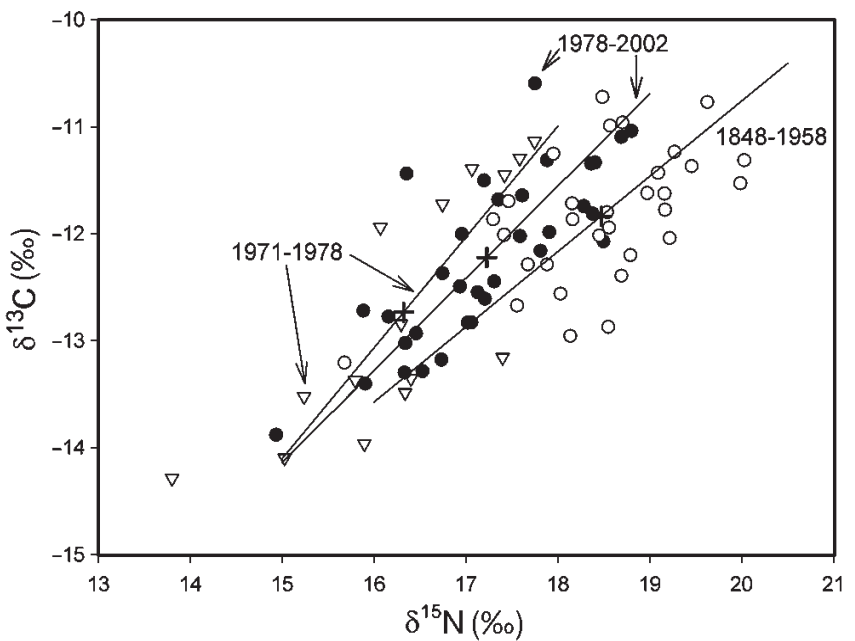

Fig. 3. Phocoena phocoena. Bivariate plot of stable isotope values in 3 groups identified by discontinuity analysis. Lines were fitted by standardised major axis (SMA) analysis. Arrows associate lines and data symbols with respective groups of data. Means are indicated by crosses

January 1978. Therefore, data were arranged into 3 groups of apparent relative stability: 1848 to 1958 $(\mathrm{n}=31), 1971$ to $1978(\mathrm{n}=15)$ and 1978 to 2002 $\left(\mathrm{n}=33\right.$ ). Bivariate relationships between $\delta^{15} \mathrm{~N}$ and $\delta^{13} \mathrm{C}$ were analysed by fitting SMA lines to data from these groups (Table 1, Fig. 3). Slopes were not significantly different among groups and a common slope of 0.851 was calculated $(95 \% \mathrm{CI}, 0.725$ to 1.000$)$. There were significant shifts in elevation between groups (ANOVA, $F=15.583, \mathrm{df}=2, \mathrm{p}<0.001$; variances homogeneous across groups) and significant shifts along the common slope (ANOVA, $F=18.242$, $\mathrm{df}=2, \mathrm{p}<0.001$; variances homogeneous across groups; Table 2).

Within the 1978-2002 group identified by the discontinuity analysis, males $\left(\delta^{15} \mathrm{~N}=17.9 \pm 0.67\right)$ were significantly more enriched in ${ }^{15} \mathrm{~N}$ than females $\left(\delta^{15} \mathrm{~N}=16.7 \pm 0.89\right)(\mathrm{t}=3.208, \mathrm{p}=0.005$, $\mathrm{df}=19$ ). There were no differences between sexes within the other 2 groups nor were there any differences between sexes in any of the data subsets with respect to $\delta^{13} \mathrm{C}$.

\section{DISCUSSION}

This analysis documents a change in the stable isotope abundances of both ${ }^{15} \mathrm{~N}$ and ${ }^{13} \mathrm{C}$ in harbour porpoises in the southern North Sea over the last century and a half. A weakness in using 
stranded animals for such a study is that the animals have different ages, sexes and conditions. However, other researchers (Das et al. 2003, 2004b) have shown that stable isotope ratios of stranded harbour porpoises are similar among animals in good, moderate or poor body condition. Nursing pups have higher $\delta^{15} \mathrm{~N}$ than juveniles and adults since they are functionally at a higher trophic level, but there is no isotope effect of age in juvenile and adult animals, although adult males have been reported to have lower $\delta^{15} \mathrm{~N}$ than adult females and juveniles (Das et al. 2003). The difference noted in the present study in terms of ${ }^{15} \mathrm{~N}$ enrichment between males and females in the 1978-2002 data subset indicates possible trophic segregation between the sexes at this time (but not earlier). We found males to be more enriched relative to females and in the Black Sea, Das et al. (2004a) found juvenile males to be more enriched relative to adult males and females.

In our data set, males and females are evenly dispersed and there is no difference between sexes with respect to $\delta^{15} \mathrm{~N}$ in the material as a whole. Thus, the temporal trends observed in the data set cannot be related to gender. The high $\delta^{15} \mathrm{~N}$ of the carcass that had been buried for 5 yr probably reflects the faster rate of microbial degradation of isotopically light protein making the remaining collagen isotopically heavier (Balzer et al. 1997) and/or contamination.

\section{Causes of the change in stable isotope abundances}

To determine the cause of the change documented here in isotope abundances in harbour porpoise skeletons, information is needed as to whether changes have occurred at other levels of the food web in the North Sea. We have not been able to find any other time series for isotope distributions in marine plants or animals in the North Sea, nor have we been able to locate suitable material upon which we could determine isotope signatures in order to create a time series of relevance for the base of the food web. Thus, we are unable to identify whether the cause of the observed change in isotope signature in harbour porpoises is the result of a change in isotope signature at the base of the food web that propagates up to the top predators or whether the cause is an external perturbation (i.e. fishing pressure) of the food web structure itself.

Interestingly, a study (Lee et al. 2005) on baleen whales done in waters north of Alaska reports a steady decline in their $\delta^{15} \mathrm{~N}$ during the period from the 1950s until 2000. Baleen whales feed at the lowest levels of the food web. Thus, the decline in $\delta^{15} \mathrm{~N}$ observed in that study could suggest a change in isotope signature in the nitrogen entering the food web. That possibility must also be considered for the changes in $\delta^{15} \mathrm{~N}$ noted in the present study for harbour porpoises. However, we see no a priori reason to suggest that such a change has taken place in the North Sea.

\section{Eutrophication}

It is true that, during the period of study, eutrophication of coastal regions has occurred which may have resulted in a contribution of land-derived nitrogen in the diet of porpoises that was greater in the later than in the early part of the study period. However, the pattern of change observed in the porpoise $\delta^{15} \mathrm{~N}$ signatures does not fit the known temporal change in nutrient input to coastal waters from anthropogenic sources. In fresh and coastal marine water systems (Mariotti et al. 1984, McClelland et al. 1997, McClelland \& Valiela 1998), a clear signal in the form of an increase in $\delta^{15} \mathrm{~N}$ signatures has been seen with population increase in the watershed. This enrichment in $\delta^{15} \mathrm{~N}$ is a consequence of the input of sewage from land into the aquatic system. A reduction in $\delta^{15} \mathrm{~N}$ signature and not an increase is seen in the present data set. Thus, it seems unlikely that sewage input to the North Sea over the course of our study period can explain the observed change in $\delta^{15} \mathrm{~N}$ signal.

When anthropogenic input of nitrogen to aquatic ecosystems is dominated by direct runoff of artificial fertilisers, on the other hand, a reduction in the $\delta^{15} \mathrm{~N}$ signal can be predicted (as artificial fertilisers are based on $\mathrm{N}$ fixed from the atmosphere). Use of artificial fertilisers around the North Sea increased steadily after World War II and until the 1980s (Richardson 1996). The decrease in $\delta^{15} \mathrm{~N}$ enrichment observed in the present study in harbour porpoise bones appears to stop in the mid-1970s. Thus, if the observed decrease in $\delta^{15} \mathrm{~N}$ was the result of fertiliser runoff to the North Sea, we would not have expected to see the decrease stop in the 1970s. Furthermore, we note that in the nearby Baltic Sea, isotope studies have indicated that land-derived nitrate is not the dominant nitrogen source which has been fuelling the increase in sedimentary organic carbon in the Baltic Sea since 1965 and that the land-derived nitrogen signal is essentially found only in the near-coast waters (Struck et al. 1998). If the same holds true for the North Sea, it would seem unlikely that the land-derived nitrogen signal would dominate in the harbour porpoises' diet.

An increase in nitrogen fixation activity of surface phytoplankton would also be predicted to lower the $\delta^{15} \mathrm{~N}$ signal in a food web. We note, however, that nitrogen-fixing organisms are not known to be plentiful in the North Sea and no information is available as to potential changes in their abundance over time. Finally, Duce et al. (2008) have reported increased 
atmospheric anthropogenic nitrogen deposition to the oceans in magnitudes globally approaching the level of nitrogen fixation. This nitrogen source is likely to be ${ }^{15} \mathrm{~N}$-depleted but its contribution to the $\delta^{15} \mathrm{~N}$ signature of the photosynthetically available $\mathrm{N}$ pool in a highnutrient area like the North Sea is unknown.

\section{Increasing concentrations of $\mathrm{CO}_{2}$ in surface waters}

The observed declining trend in $\delta^{13} \mathrm{C}$ may at least partially result from the invasion of ocean surface waters by anthropogenic $\mathrm{CO}_{2}$ (Cullen et al. 2001). Both the lighter anthropogenic carbon causing a decline in $\delta^{13} \mathrm{C}_{\mathrm{aq}}$ of surface waters (i.e. the ${ }^{13} \mathrm{C}$ Suess effect) and an increase in dissolved free $\mathrm{CO}_{2}$ will lower the $\delta^{13} \mathrm{C}$ of marine primary producers, and we note that the overall declining trend in $\delta^{13} \mathrm{C}$ in our data set is of the same order of magnitude as the estimated global Suess effect of about $-0.16 \%$ per decade (Gruber et al. 1999, Quay et al. 2003). We believe, then, that a part of the decline we see in $\delta^{13} \mathrm{C}$ may be attributed to anthropogenic changes in carbon composition of the atmosphere. However, changes in atmospheric $\mathrm{CO}_{2}$ concentrations and isotope signatures cannot explain the increase in $\delta^{13} \mathrm{C}$ we observe between the 1971-1978 and the 1978-2002 groups. This increase implies that changes in food web structure or changes at the base of the food web have occurred.

\section{Changes in food web structure}

It is interesting to note that the slope of the relationship between $\delta^{15} \mathrm{~N}$ and $\delta^{13} \mathrm{C}$ does not differ significantly throughout the study period. Comparison of our data with those reported by others (Angerbjörn et al. 2006) for porpoises from the Baltic and Kattegat areas shows that the slope of the relationship between $\delta^{15} \mathrm{~N}$ and $\delta^{13} \mathrm{C}$ in their data is consistent with the slopes that we report here (common slope 0.826; data not shown). A controlled feeding experiment examining the influence of diet on isotope signals in captive seals (Hobson et al. 1996) has, in accordance with our observations, suggested that substantial trophic enrichment may be associated with $\delta^{13} \mathrm{C}$ in marine carnivores (see also the reviews by Kelly 2000, Dalerum \& Angerbjörn 2005). Indications of trophic enrichment in ${ }^{13} \mathrm{C}$ have also been found in analyses of whole food webs (e.g. Rau et al. 1983, Hobson et al. 2002). Enrichment in ${ }^{13} \mathrm{C}$ should theoretically be greater in birds and mammals with high rates of respiration relative to growth than in poikilothermic animals because respiratory $\mathrm{CO}_{2}$ is isotopically lighter than assimilated carbon (McCutchan et al. 2003). Thus, when a larger fraction of assimilated carbon is respired, the tissues of the animal will be relatively enriched in ${ }^{13} \mathrm{C}$.
We cannot rule out a contribution of anthropogenic effects to the changes in $\delta^{13} \mathrm{C}$ and $\delta^{15} \mathrm{~N}$ signatures reported here for harbour porpoise skeletons. Nor can we identify what change(s) in food web structure have given rise to the observed changes in isotope signatures. Nevertheless, given the information available concerning changes in size distributions of fish in the North Sea during the latter half of the 20th century, we argue that the observed decrease in harbour porpoise $\delta^{15} \mathrm{~N}$ and concurrent changes in $\delta^{13} \mathrm{C}$ may well be the result of a change in diet composition available to these animals. We interpret the shifts in the SMA analysis as shifts in trophic level of feeding and we believe the observed change in abundance of ${ }^{15} \mathrm{~N}$ suggests a change in the structure of the pelagic food web whereby animals from lower trophic levels are relatively more abundant in the North Sea in the period since the 1960s than earlier in the study period.

The size of fish may influence their trophic level and hence their $\delta^{15} \mathrm{~N}$ signature. Jennings et al. (2002) determined the relationship between $\delta^{15} \mathrm{~N}$ and body size for 31 species of North Sea fish. For 27 of these, there was a strong positive relationship between body size and $\delta^{15} \mathrm{~N}$. The same study demonstrated a longterm decline in the average size of fish. At least 2 other studies based on fisheries monitoring data have also demonstrated a decrease in the size of fish in the North Sea over short periods in the latter part of the past century (Rice \& Gislason 1996, Rijnsdorp et al. 1996).

A change from benthic to pelagic feeding may also affect $\delta^{15} \mathrm{~N}$ signatures in organisms. Porpoises taken as by-catch from Iceland and Norway have considerably lower $\delta^{15} \mathrm{~N}$ levels than porpoises from the North Sea. This is believed to be a reflection of a more pelagic diet for the porpoises from Iceland and Norway (Das et al. 2004b), although caution should be exerted when comparing isotope signatures between sites. Thus, the lower porpoise $\delta^{15} \mathrm{~N}$ and the shift along the common axis in the bivariate relationship between $\delta^{13} \mathrm{C}$ and $\delta^{15} \mathrm{~N}$ demonstrated in the present study may reflect these animals now feeding on smaller fish and/or having a higher proportion of pelagic plankton-feeding fish in their diet than prior to the 1960s. As there is, however, the higher $\delta^{13} \mathrm{C}$ signal seen in our data that suggests a possible shift towards a more benthic diet, we argue that the change in $\delta^{15} \mathrm{~N}$ signature noted in our data may suggest feeding on smaller fish in recent decades.

\section{Relationship to climate}

Because changes in the abundance of some fish stocks have been shown to correlate with climate signals (Svendsen et al. 1995, Alheit \& Hagen 1997, Attrill 
\& Power 2002, Brander 2005, Henderson \& Seaby 2005), we investigated whether we could find a correlation with the most obvious climate signal in the North Sea, i.e. the North Atlantic Oscillation (NAO) index, and the apparent change in harbour porpoise diet. However, the variation in $\delta^{15} \mathrm{~N}$ in harbour porpoises exhibited no significant correlation with the NAO index (Hurrell 1995; data accessed 4 December 2006 from: www.cgd. ucar.edu/cas/jhurrell/indices.html) itself, or with the NAO index with 1, 2, 3, 4 and 5 yr delay, respectively (Spearman's rank correlation test, $\mathrm{p}=0.076$ or higher).

The present study demonstrates a temporal change in the diet of harbour porpoises in the southern North Sea. Because harbour porpoises are generalist feeders, the change in diet suggests a change in ecosystem structure. We cannot identify with certainty what the cause of this change might be. However, we suggest that the change in isotope signatures may be a result of the fact that animals belonging to the higher trophic levels are less abundant now than they were in the first half of the 20th century and before. We cannot establish the cause of this change. As noted above, however, others (Pauly et al. 1998, Pinnegar et al. 2002) have used fish-catch data to argue that intensive fisheries have led to a change in ecosystems whereby lower trophic levels are now more dominant in marine ecosystems than previously. The data presented in the present study provide independent evidence for the North Sea of a possible change in trophic structure of the ecosystem of the type suggested by these researchers. The timing of the apparent change in the diet of harbour porpoises agrees well with the timing of the trophic changes indicated by fish landings from the eastern North Atlantic (Pauly et al. 1998), where the North Sea signal in fish landings would be expected to be strong.

Interestingly, a study by Wainright et al. (1993) examining stable isotope signatures in fish scales in the Georges Bank (off Newfoundland) food web found a significant decline in $\delta^{15} \mathrm{~N}$ in haddock over the study period 1929 to 1987. Those authors did not find a significant effect of fishing effort itself on stable isotope distribution patterns. However, they did note that 2 large increases in fishing mortality began immediately prior to the 2 largest decreases in $\delta^{15} \mathrm{~N}$ in haddock scales. They suggested that the observed decline in $\delta^{15} \mathrm{~N}$ may be an indication of a collapse in trophic structure towards a simpler food web with fewer trophic levels. A similar mechanism may explain the decline in $\delta^{15} \mathrm{~N}$ in North Sea harbour porpoises.

The strength of the analysis presented here is that the signal suggesting a change in ecosystem structure is derived directly from the food web itself rather than fisheries-catch data. In addition, the present study extends the historical time frame over which food web structure in the North Sea can be examined.
Acknowledgements. We are indebted to Dr. C. Smeenk, curator of mammals at the National Museum of Natural History in Leiden, for permission to extract samples from the museum specimens.

\section{LITERATURE CITED}

Alheit J, Hagen E (1997) Long-term climate forcing of European herring and sardine populations. Fish Oceanogr 6: $130-139$

Angerbjörn A, Börjeson P, Brandberg K (2006) Stable isotope analysis of harbour porpoises and their prey from the Baltic and Kattegat/Skagerrak Seas. Mar Biol Res 2:411-419

Attrill MJ, Power M (2002) Climatic influence on a marine fish assemblage. Nature 417:275-278

Balzer A, Gleixner G, Grupe G, Schmidt HL, Schramm S, Tuban-Just S (1997) In vitro decomposition of bone collagen by soil bacteria: the implications for stable isotope analysis in archaeometry. Archaeometry 39:415-429

Brander K (2005) Cod recruitment is strongly affected by climate when stock biomass is low. ICES J Mar Sci 62: 339-343

Cabana G, Rasmussen JB (1996) Comparison of aquatic food chains using nitrogen isotopes. Proc Natl Acad Sci USA 93:10844-10847

Cullen JT, Rosenthal Y, Falkowski PG (2001) The effect of anthropogenic $\mathrm{CO}_{2}$ on the carbon isotope composition of marine phytoplankton. Limnol Oceanogr 46:996-998

> Dalerum F, Angerbjörn A (2005) Resolving temporal variation in vertebrate diets using naturally occurring stable isotopes. Oecologia 144:647-658

Das K, Lepoint G, Leroy Y, Bouquegneau JM (2003) Marine mammals from the southern North Sea: feeding ecology data from $\delta^{13} \mathrm{C}$ and $\delta^{15} \mathrm{~N}$ measurements. Mar Ecol Prog Ser 263:287-298

> Das K, Holsbeek L, Browning J, Siebert U, Birkun A Jr, Bouquegneau JM (2004a) Trace metal and stable isotope measurements $\left(\delta^{13} \mathrm{C}\right.$ and $\left.\delta^{15} \mathrm{~N}\right)$ in the harbour porpoise Phocoena phocoena relicta from the Black Sea. Environ Pollut 131:197-204

Das K, Siebert U, Fontaine M, Jauniaux T, Holsbeek L, Bouquegneau JM (2004b) Ecological and pathological factors related to trace metal concentrations in harbour porpoises Phocoena phocoena from the North Sea and adjacent areas. Mar Ecol Prog Ser 281:283-295

> Duce RA, LaRoche J, Altieri K, Arrigo KR and others (2008) Impacts of atmospheric anthropogenic nitrogen on the open ocean. Science 320:893-897

Essington TE, Beaudreau AH, Wiedenmann J (2006) Fishing through marine food webs. Proc Natl Acad Sci USA 103:3171-3175

Gruber N, Keeling CD, Bacastow RB, Guenther PR and others (1999) Spatiotemporal patterns of carbon-13 in the global surface oceans and the oceanic Suess effect. Global Biogeochem Cycles 13:307-335

> Henderson PA, Seaby RM (2005) The role of climate in determining the temporal variation in abundance, recruitment and growth of sole Solea solea in the Bristol Channel. J Mar Biol Assoc UK 85:197-204

> Hobson KA, Schell DM, Renouf D, Noseworthy E (1996) Stable carbon and nitrogen isotopic fractionation between diet and tissues of captive seals: implications for dietary reconstructions involving marine mammals. Can J Fish Aquat Sci 53:528-533

> Hobson KA, Fisk A, Karnovsky N, Holst M, Gagnon JM, Fortier M (2002) A stable isotope $\left(\delta^{13} \mathrm{C}, \delta^{15} \mathrm{~N}\right)$ model for the 
North Water food web: implications for evaluating trophodynamics and the flow of energy and contaminants. DeepSea Res II 49:5131-5150

Hurrell JW (1995) Decadal trends in the North Atlantic oscillation: regional temperatures and precipitation. Science 269:676-679

> Jennings S, Greenstreet SPR, Hill L, Piet GJ, Pinnegar JK, Warr KJ (2002) Long-term trends in the trophic structure of the North Sea fish community: evidence from stableisotope analysis, size-spectra and community metrics. Mar Biol 141:1085-1097

Kelly JF (2000) Stable isotopes of carbon and nitrogen in the study of avian and mammalian trophic ecology. Can J Zool 78:1-27

Lee SH, Schell DM, McDonald TL, Richardson WJ (2005) Regional and seasonal feeding by bowhead whales Balaena mysticetus as indicated by stable isotope ratios. Mar Ecol Prog Ser 285:271-287

Ludwig JA, Cornelius JM (1987) Locating discontinuities along ecological gradients. Ecology 68:448-450

Mariotti A, Lancelot C, Billen G (1984) Natural isotopic composition of nitrogen as a tracer of origin for suspended organic material in the Scheldt estuary. Geochim Cosmochim Acta 48:549-555

McClelland JW, Valiela I (1998) Linking nitrogen in estuarine producers to land-driven sources. Limnol Oceanogr 43: 577-585

McClelland JW, Valiela I, Michener RH (1997) Nitrogenstable isotope signatures in estuarine food webs: a record of increasing urbanization in coastal watersheds. Limnol Oceanogr 42:930-937

McCutchan JH Jr, Lewis WM, Kendall C, McGrath CC (2003) Variation in trophic shift for stable isotope ratios of carbon, nitrogen, and sulphur. Oikos 102:378-390

Michener RH, Schell DM (1994) Stable isotope ratios as tracers in marine aquatic food webs. In: Lajtha $\mathrm{K}$, Michener $\mathrm{RH}$ (eds) Stable isotopes in ecology and environmental science. Blackwell, Oxford, p 138-157

Minami M, Muto H, Nakamura T (2004) Chemical techniques to extract organic fractions from fossil bones for accurate ${ }^{14} \mathrm{C}$ dating. Nucl Instrum Methods Phys Res B 223-224: 302-307

Pauly D, Christensen V, Dalsgaard J, Froese R, Torres F (1998) Fishing down marine food webs. Science 279:860-863

Pinnegar JK, Jennings S, O'Brien CM, Polunin NVC (2002) Long-term changes in the trophic level of the Celtic Sea fish community and fish market price distribution. J Appl Ecol 39:377-390

Post DM (2002) Using stable isotopes to estimate trophic position: models, methods, and assumptions. Ecology 83: 703-718

Quay P, Sonnerup R, Westby T, Stutsman J, McNichol A (2003) Changes in the ${ }^{13} \mathrm{C} /{ }^{12} \mathrm{C}$ of dissolved inorganic car-

Editorial responsibility: Otto Kinne,

Oldendorf/Luhe, Germany bon in the ocean as a tracer of anthropogenic $\mathrm{CO}_{2}$ uptake. Global Biogeochem Cycles 17:1004

Ramsey CB, Higham T, Bowles A, Hedges R (2004) Improvements to the pre-treatment of bone at Oxford. Radiocarbon 46:155-163

> Rau GH, Mearns AJ, Young DR, Olson RJ, Schafer HA, Kaplan IR (1983) Animal ${ }^{13} \mathrm{C} /{ }^{12} \mathrm{C}$ correlates with trophic level in pelagic food webs. Ecology 64:1314-1318

> Rice J, Gislason H (1996) Patterns of change in the size spectra of numbers and diversity of the North Sea fish assemblage, as reflected in surveys and models. ICES J Mar Sci 53:1214-1225

Richardson K (1996) Conclusion, research and eutrophication control. In: Jørgensen BB, Richardson K (eds) Eutrophication in coastal marine ecosystems. Coastal and estuarine studies, Vol 52. American Geophysical Union, Washington, DC, p 243-267

> Rijnsdorp AD, van Leeuwen PI, Daan N, Heessen HJL (1996) Changes in abundance of demersal fish species in the North Sea between 1906-1909 and 1990-1995. ICES J Mar Sci 53:1054-1062

Santos MB, Pierce GJ (2003) The diet of harbour porpoise (Phocoena phocoena) in the Northeast Atlantic. Oceanogr Mar Biol Annu Rev 41:355-390

Scrimgeour CM, Robinson D (2003) Stable isotope analysis and applications. In: Smith KA, Cresser MS (eds) Soil and environmental analysis: modern instrumental techniques. Marcel Dekker, London, p 381-431

Struck U, Voss M, von Bodungen B, Mumm N (1998) Stable isotopes of nitrogen in fossil cladoceran exoskeletons: implications for nitrogen sources in the central Baltic Sea during the past century. Naturwissenschaften 85: 597-603

Svendsen E, Aglen A, Iversen SA, Skagen DW, Smestad O (1995) Influence of climate on recruitment and migration of fish stocks in the North Sea. In: Beamish RJ (ed) Climate change and northern fish populations. Can Spec Publ Fish Aquat Sci 121:641-653

> Vander Zanden MJ, Casselman JM, Rasmussen JB (1999a) Stable isotope evidence for the food web consequences of species invasions in lakes. Nature 401:464-467

Vander Zanden MJ, Schuter BJ, Lester N, Rasmussen JB (1999b) Patterns of food chain length in lakes: a stable isotope study. Am Nat 154:406-416

- Wainright SC, Fogarty MJ, Greenfield RC, Fry B (1993) Longterm changes in the Georges Bank food web: trends in stable isotopic compositions of fish scales. Mar Biol 115: 481-493

Warton DI, Wright IJ, Falster DS, Westoby M (2006) Bivariate line-fitting methods for allometry. Biol Rev Camb Philos Soc 81:259-291

Webster R (1973) Automatic soil-boundary location from transect data. Math Geol 5:27-37

Submitted: September 12, 2007; Accepted: July 3, 2008

Proofs received from author(s): September 5, 2008 